\title{
Reseptskriving - fra oppskrift til produktnavn
}

Inntil første tiår på 1900-tallet foregikk det meste av legemiddelproduksjonen i de enkelte apotek. Legene skrev en detaljert liste over hvilke preparater som skulle inngå i legemidlet, og apotekeren fremstilte dem. Å skrive resepter var en vanskelig kunst, på linje med oppskriftsangivelse i matlagingen. Rundt 1900 tiltok imidlertid legemiddelbruken voldsomt, og legemiddelproduksjonen ble mekanisert og sentralisert i større farmasøytiske firmaer. Det som trengtes på resepten var ikke lenger en oppskrift, men angivelse av et produktnavn. Med dette ble legemiddelfeltet økende kommersialisert, og patentering ble stadig viktigere. Nedenfor er en redegjørelse skrevet av Norges første professor i farmakologi, Paul Edvard Poulsson (1858-1935)( Tidsskr Nor Lægeforen 1932; 52: -187)

\section{Om rasjonell og økonomisk forskrivning av lægemidler.}

Av E. Poulsson, Oslo.

\section{$(\ldots)$}

I den senere tid har den ovenfor skisserte moderne utvikling imidlertid også medført skyggesider, som ikke er av det gode, men det står i lægenes makt iallfall i nogen grad å bekjempe. Det gjelder først og fremst den overhåndtagende anvendelse av de såkalte «be skyt te de navn» hvorved et ikke tidsbe gren set mo no pol skapes. Vedkommende substans utstyres med et fantasinavn, som kun navnets eier kan benytte. Selv for lengst kjente, overmåde enkle kjemiske forbindelser, hvis fremstilling ingen vanskelighet tilbyr, kan ved et behendig valgt, lettvint, suggestivt virkende navn økonomisk utnyttes på en måte som pålegger patientene meget store og helt overflødige utgifter. Veien til å skaffe de navnebeskyttede midler avsetning ligger selvsagt i en intens reklame, som likeså selvsagt må betales av patienten. Sistnevnte har sine naturlige forsvarere i det nødvendige mellemledd mellem dem og fabrikantene, nemlig lægene, og forsvaret består i at lægene ikke benytter de beskyttede fantasinavn, men følger farmakopøenes kjemiske videnskapelige nomenklatur. (...) 